\title{
Ecological Engineering of Intercropping in Blackgram Promotes Services of Coccinellids and Suppress Aphis gossypii (Glover)
}

\author{
S. Lokesh ${ }^{1 *}$, N. Muthukrishnan ${ }^{1}$, N. Ganapathy ${ }^{1}$, \\ J.R. Kannan Bapu ${ }^{2}$ and E. Somasundaram ${ }^{3}$ \\ ${ }^{1}$ Department of Agricultural Entomology, TNAU, Coimbatore 641 003, Tamil Nadu, India \\ ${ }^{2}$ Sethu Bhaskara Agricultural College and Research Foundation, \\ Karaikudi Taluk, 630 306, Tamil Nadu, India \\ ${ }^{3}$ Department of Sustainable organic agriculture, TNAU, Coimbatore 641003 , Tamil Nadu, India \\ *Corresponding author
}

\section{A B S T R A C T}

\begin{abstract}
Keywords
Ecological engineering, Blackgram, Intercrops, Coccinellids, Aphis gossypii.

Article Info

Accepted:

15 September 2017

Available Online:

10 November 2017 intercrops (sunflower, sesame, sorghum, maize, marigold and okra) on the biocontrol services of predatory coccinellids on Aphis gossypii (Glover) in blackgram (cv. VBN 3). Blackgram + maize intercropping system significantly influenced maximum coccinellids on blackgram (4.67 adults/ plant) along with highest pest defender ratio (PDR) of 1: 2.31, occurrence ratio (OR) of coccinellids (1.43), minimum A. gossypii (5.48 nymphs and adults / terminal shoot), preference ratio (PR) of $A$. gossypii (1.10) and maximum $\mathrm{BC}$ ratio (1: 4.84). Blackgram with sunflower, marigold, sorghum, sesame and okra intercropping systems also effected for higher population of coccinellids; higher PDR and OR of coccinellids; and minimum $A$. gossypii and PR; and moderate $\mathrm{BC}$ ratios than blackgram alone (1.87 coccinellids/plant; 1: 0.37 PDR; 7.2 A. gossypii/terminal shoot; and BC ratio of 1: 2.11). Maximum coccinellids was also observed on maize with highest PDR followed by sunflower and marigold. Sorghum, sesame and okra had higher coccinellids. Olfactometer studies revealed the order of preference of coccinellids towards leaves and flowers as maize, sunflower, marigold, sorghum, sesame and okra.
\end{abstract}

We conducted a 2-year experiment in south India examining the effects of non-pulse

\section{Introduction}

Blackgram is one of the richest vegetable proteins of human diet, and contributes $10 \%$ to the national pulse production (1.81 million tonnes) from an area of $13 \%$ (3.25 million ha) with the productivity of $463 \mathrm{~kg} \mathrm{ha}^{-1}$ (Anon., 2012). In Tamil Nadu, blackgram dominates the pulse cropping pattern (in 3.41 lakh ha with 1.21 lakh tonnes production and productivity of $355 \mathrm{~kg} \mathrm{ha}^{-1)}$ (Agropedia, 2016). Moderate to heavy infestation by aphids, leaf hoppers, thrips, whiteflies, pod bugs, stink bugs, gram pod borer, spotted pod borer, field bean pod borer, pod fly and pulse beetle is a major biotic stress and result in 25 to 60 per cent yield loss. Dominant pestcontrol strategy has been the use of insecticides. But pest population has developed high levels of resistance, and insecticides showed toxicity to non-target parasitoids and predators of pulse ecosystem. Indian blackgram ecosystem in general is a rich source of biodiversity of beneficial 
arthropods and insect pests. Ecological engineering cropping methods has been emerged as a paradigm that relies on the use of habitat manipulation to enhance the activities of natural enemies and to aim at minimal or zero insecticide use Gurr et al., (2004). The goal of ecological engineering is to protect crops from insect pest damage by promoting biocontrol service Cullen et al., (2008) by planting flowering crops in field margins adjacent to crop fields which can provide non-prey foods and other necessary resources for natural enemies of crop pests, when flowers are not available in main crop Wanner et al., (2006). Previous studies on habitat manipulation significantly augmented the entomophages and increased natural suppression of pests around blackgram Lokesh et al., (2017), rice Chandrasekar et al., (2016), okra (Deepika, 2016), and cotton Muthukrishnan et al., (2015). However, paucity of information exists on the role of blackgram + non pulses crop habitats in increasing entomophages and enhancing natural pest suppression. Therefore, this study aims at knowing the significances of blackgram and other pulse crop diversities in the conservation biological control.

\section{Materials and Methods}

First and second season experiments were conducted during rabi season (October to January) of 2015-16 and 2016-17 at Viraliur, Thondamuthure Union, Coimbatore District, Tamil Nadu. The experimental sites are situated approximately $10^{\circ} 97^{\prime} \mathrm{N}$ latitude, $76^{\circ}$ 86' E longitude and $411 \mathrm{~m}$ above mean sea level (MSL). Experiments were laid out in Randomized Block Design (RBD) consisting seven treatments and three replications with a field plot size was $5 \times 5 \mathrm{~m}^{2}$. Blackgram (cv. VBN 3) was sown as main crop with a spacing of $30 \times 10 \mathrm{~cm}$. Sunflower (cv. CO 2), sesame (cv. TMV 7), sorghum (cv. CO 30), maize (cv. COMH 6), marigold (cv. MDU 1) and okra (cv. COBhH 1) were raised as intercrops with blackgram separately (three rows in one meter area in the inter). All intercrops were sown at 25 days in advance to blackgram sowing to facilitate for the synchronized flowering of both blackgram and non-pulse flowering crops. Normal agronomic practices like fertilizer application and manual weeding were carried out as per the recommended crop production practices of Tamil Nadu Agricultural University Anonymous (2016). No chemical pesticides were applied throughout the season.

In situ observations on the population of grubs and adults of various species of coccinellids (number/plant) and population of nymphs and adults of A. gossypii (number/ terminal shoot) on blackgram and intercrops from 10 randomly selected plants from each replication were made. Standard taxonomic keys as prescribed by (Poorani, 2002) were used for the identification of coccinellid species observed during the study. Observations were taken during early morning hours at seven days interval from 15 days after sowing (DAS) to 64 DAS. Based on the observations, Occurrence ratio (OR) of coccinellids, preference ratio (PR) of aphids and Pest defender ratio (PDR) were estimated by using the formulae as used by (Muthukrishnan and Dhanasekaran, 2014). $(\mathrm{PDR}=$ Population of natural enemies on blackgram or intercrops / population of $A$. gossypii on blackgram or intercrops; OR = Population of natural enemies on intercrops / population of natural enemies on blackgram; $\mathrm{PR}=$ Population of pests on intercrops / Population of pests on blackgram). Cost benefit ratio was estimated by the formula of cost of produce / cost of cultivation + cost of plant protection (Akila et al., 1994).

Olfactometer studies were conducted using eight arms Olfactometer. About ten gram of healthy plant leaves of individual intercrop 
were kept in individual arm and firmly closed with a lid. The inlet of the Olfactometer on the top center place was connected to an aquarium pump (220-240 volt Ac) to release the pressure. Out of the eight arms, leaf samples were kept in six arms and two arms were treated as control. The medical air was passed from aquarium pump at the rate of 4 lit/min into the Olfactometer. Twenty numbers of coccinellids (male and female) were released to the Olfactometer through a central hole which also served as odour exit hole. Observations were made on number of predators settled on each arms at 5, 10, 15 and 20 MAR (Minutes After Release) for their host preference. Similar methodology was followed for the flower samples of all the intercrops. The experiments were replicated four times. The data from field experiments and Olfactometer meter experiments were scrutinized by RBD and CRBD analysis of variance (ANOVA) respectively after getting transformed into $\sqrt{\mathrm{x}}+0.5$ using AGRES Gomez (1984). Pooled RBD ANOVA was done using IRRI STAR statistical package. Critical difference values were calculated at five per cent probability level and treatments mean values were compared using Duncan's Multiple Range Test (DMRT) as per (Gomez and Gomez, 1984).

\section{Results and Discussion}

\section{Coccinellid species observed}

Coccinellid species like Chielomenus sexmaculata, Coccinella septumpunctata and Brumoides suturalis (Poorani, 2002) were observed.

\section{Population of coccinellids on blackgram}

Figure 1 depicts observations on the population of coccinellids on blackgram at 15 , $22,29,36,43,50,57$ and 64 DAS of first and second year experiments. In the first season experiment, mean population of coccinellids ranged from 2.08 to 4.92 per plant on blackgram. There was significant variation due to intercropping systems. Mean data revealed that maize, sunflower and marigold intercrops most significantly influenced for the maximum population of coccinellids on blackgram (4.92, 4.58 and 4.46/plant respectively). Sorghum, sesame and okra intercrops also influenced for the higher population of coccinellids on blackgram (3.65, 3.55 and 3.16/ plant respectively. However, population of coccinellids was minimum (2.08 / plant) when blackgram was grown alone (Table 1). During the second season experiment, mean population varied from 1.67 to 4.42 per plant. Blackgram when intercropped with maize, sunflower, marigold and sorghum registered for the maximum population of coccinellids $(4.42,3.97,3.80$ and 3.42 / plant) when compared to blackgram alone (1.67 / plant). This was followed by sesame and okra which contributed for the population of 2.97 and 2.45 per plant (Table 1 ).

Season wise pooled mean population of coccinellids ranged from 1.87 to 4.67 per plant and significantly maximum due to maize (4.67/plant with $149.73 \%$ increase over control) and sunflower (4.27/plant with $128.34 \%$ increase) intercrops. Marigold and sorghum were the next best intercrops that influenced for the higher population of coccinellids (4.13 and 3.53 per plant with 120.86 and $88.77 \%$ increase respectively). Sesame and okra intercrops resulted in coccinellid population of 3.26 (74.33\% increase) and 2.80 (49.73\% increase) per plant. However, blackgram alone resulted in 1.87 coccinellids per plant only on blackgram (Table 1).

\section{Population of coccinellids on intercrops}

Weekly population of coccinellids on various intercrops observed during first and second season experiments are given Figure 2. In the 
first season experiment, mean population of coccinellids on various intercrops ranged from 2.60 to 4.56 per plant. Maximum coccinellids were observed on maize (4.56 / plant) and sunflower (4.10/plant). Marigold, sorghum, sesame and okra intercrops registered 3.47, 3.25, 2.93 and 2.60 coccinellids per plant respectively (Table 1). Similar trend of population of coccinellids on intercrops $(7.51,7.07,6.63,5.85,5.53$ and 4.94 / plant maize, sunflower, marigold, sesame, sorghum and okra respectively) was observed in the second season experiment. Pooled season mean population of coccinellids on intercrops ranged from 3.77 to 6.03 per plant. The order of preference of coccinellids was okra (1.17/plant), maize (1.10/plant), sorghum (1.03/plant), marigold (0.95/plant), sesame (0.88/plant) and sunflower (0.79/plant (Table 1). Occurrence ratio of coccinellids was maximum due to maize (1.43) and sunflower (1.36). This was followed by marigold (1.30) and sesame (1.26). Sorghum and okra however registered OR of 1.23 and 1.19 respectively (Table 3 ).

\section{Population of aphids on blackgram}

Population of aphids on blackgram at 15, 22, 29, 36, 43, 50, 57 and 64 DAS during first and second year experiments are given in Figure 3 . In the first season experiment, mean population varied from 4.56 to 7.84 per terminal shoot on blackgram. There was significant variation on the population due to intercropping systems. Sunflower, marigold and sesame intercrops most significantly influenced for the minimum population of aphids on blackgram (4.56, 4.88 and 5.16/ terminal shoot respectively). Okra, sorghum and maize intercrops also influenced for the lower population of aphids on blackgram (5.64, 5.89 and $6.11 /$ terminal shoot respectively. However, maximum population (7.84 / terminal shoot) was observed when blackgram was grown alone (Table 2). During the second season experiment, mean population ranged from 4.41 to 6.71 per terminal shoot. Blackgram when intercropped with sunflower, marigold and maize registered for the minimum population (4.41, 4.57 and 4.85 / terminal shoot) when compared to blackgram alone (6.71 / terminal shoot). This was followed by sorghum, sesame and okra which contributed for the population of 5.25, 5.57 and 6.71 per terminal shoot (Table 2).

Season wise pooled mean population of aphids ranged from 4.48 to 7.27 per terminal shoot and significantly minimum due to sunflower (4.48 / terminal shoot with $38.38 \%$ decrease over control), marigold (4.72 / terminal shoot with $35.08 \%$ decrease) and sesame (5.36 / terminal shoot with $26.27 \%$ decrease) intercrops. Maize and sorghum were the next best intercrops that influenced for the lower population of aphids (5.48 and 5.57 /terminal shoot with $24.62 \%$ and 23.38 $\%$ decrease respectively). Okra intercrop resulted in population of $5.75(20.91 \%$ decrease) per terminal shoot. However, nonintercropped blackgram resulted in 7.27 aphids per terminal shoot (Table 2).

\section{Population of aphids on intercrops}

Population of aphids on various intercrops observed during first and second season experiments are given Figure 4. In the first season experiment, mean population of aphids on various intercrops ranged from 3.38 to 5.69 per terminal shoot. Minimum aphids were observed on sunflower (3.83 / terminal shoot) and marigold (4.08 / terminal shoot). Sesame was the next best intercrop that influenced for the lower population of aphids (4.40 per terminal shoot). Okra and sorghum intercrops registered 4.74 and 5.35 aphids per terminal shoot respectively. Maize resulted in maximum population of aphids 5.69 per terminal shoot (Table 2). Similar trend of 
population of aphids on intercrops $(4.87,5.15$, $5.44,5.53,6.15$ and $6.35 /$ terminal shoot on sunflower, marigold, sesame, okra, sorghum and maize respectively) was observed in the second season experiment. Pooled season mean population of aphids on intercrops ranged from 4.35 to 6.02 per terminal shoot. The order of preference for minimum population of aphids was sunflower (4.35 / terminal shoot), marigold (4.61/ terminal shoot), sesame (4.92/ terminal shoot), okra (5.13 / terminal shoot), sorghum (5.75/ terminal shoot) and maize (6.02 / terminal shoot) (Table 2). Preference ratio of aphids was minimum due to sunflower (0.79) and sesame (0.88). This was followed by marigold (0.95) and sorghum (1.03). Maize and okra however registered PR of 1.10 and 1.17 respectively (Table 3 ).
Pest defender ratio (PDR) ranged from 1: 2.31 to 1: 0.37 due to various intercrops. Blackgram + maize intercropping system influenced for maximum PDR. Sunflower and marigold contributed for higher PDR of 1 : 1.77 and 1: 1.66 respectively. PDR of $1: 1.50$, 1: 1.18 and 1: 0.89 were resulted in due to sorghum, sesame and okra.

Blackgram alone however accounted for the minimum PDR of 1: 0. 37. Cost benefit ratio (CBR) was maximum (1: 4.96) due to blackgram + sunflower intercropping system. This was followed by higher CBR of 1: 4.84 and 1: 4.52 due to maize and marigold. Sorghum, sesame and okra however, resulted in CBR of 1: 4.30, 1: 3.79 and 1: 3.49) when compared to blackgram which contributed 1: 2.11 .
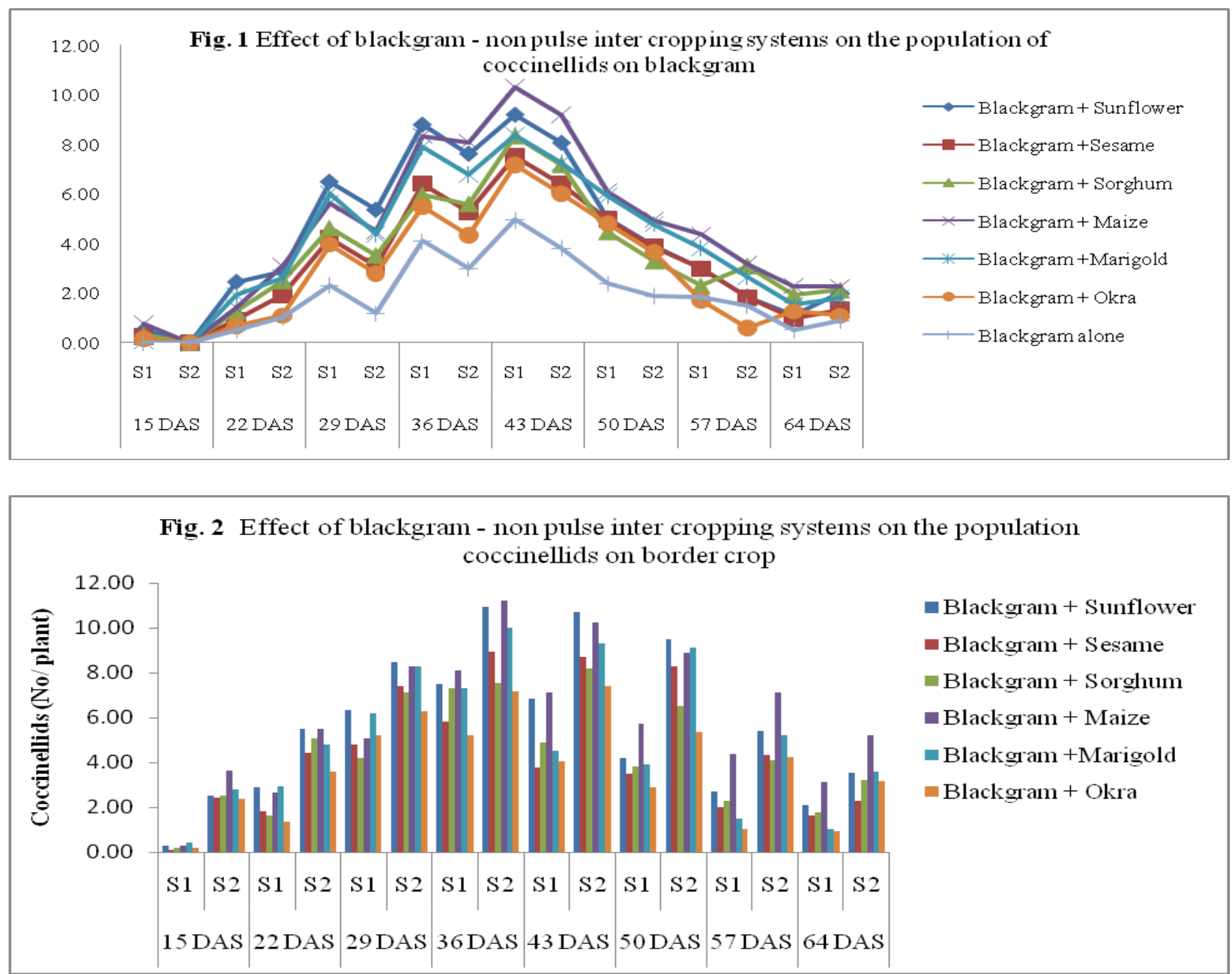

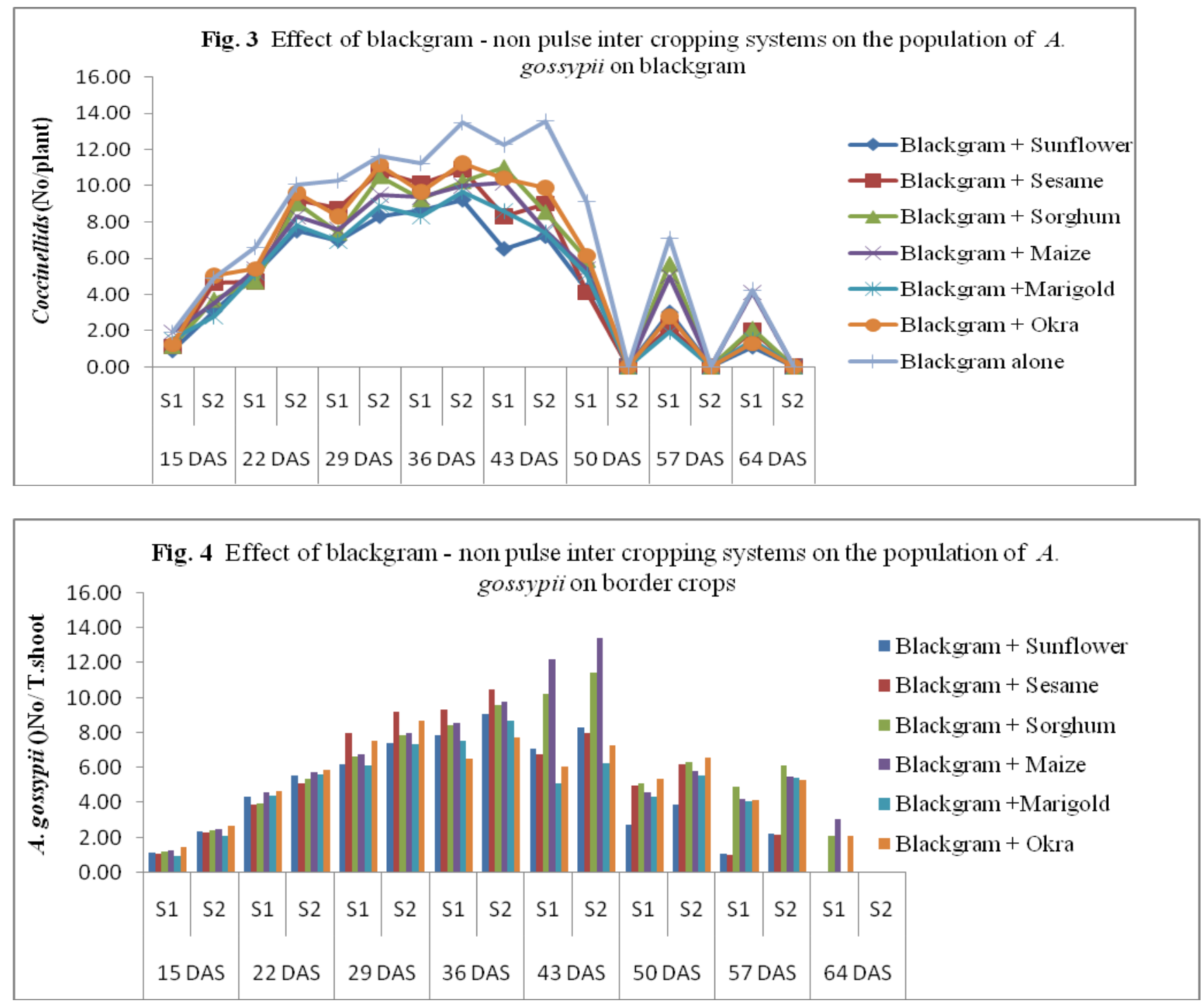

Table.1 Effect of blackgram - non pulse intercropping systems on population of coccinellids

\begin{tabular}{|l|c|c|c|c|c|c|c|}
\hline & \multicolumn{6}{|c|}{ Mean population of coccinellid predators (No./plant) on } \\
\cline { 2 - 8 } & \multicolumn{4}{|c|}{ Blackgram } & \multicolumn{3}{|c|}{ Intercrop } \\
\cline { 2 - 8 } & Season 1 & $\begin{array}{c}\text { Season } \\
\text { II }\end{array}$ & $\begin{array}{c}\text { Pooled } \\
\text { Mean }\end{array}$ & $\begin{array}{c}\text { Percent } \\
\text { increase }\end{array}$ & Season 1 & $\begin{array}{c}\text { Season } \\
\text { II }\end{array}$ & $\begin{array}{c}\text { Pooled } \\
\text { Mean }\end{array}$ \\
\hline Blackgram + Sunflower & $4.58^{\mathrm{b}}$ & $3.97^{\mathrm{b}}$ & $4.27^{\mathrm{b}}$ & 128.34 & $4.10^{\mathrm{b}}$ & $7.07^{\mathrm{ab}}$ & $5.58^{\mathrm{b}}$ \\
\hline Blackgram + Sesame & $3.55^{\mathrm{c}}$ & $2.97^{\mathrm{d}}$ & $3.26^{\mathrm{d}}$ & 74.33 & $2.93^{\mathrm{d}}$ & $5.85^{\mathrm{d}}$ & $4.38^{\mathrm{d}}$ \\
\hline Blackgram + Sorghum & $3.65^{\mathrm{c}}$ & $3.42^{\mathrm{c}}$ & $3.53^{\mathrm{c}}$ & 88.77 & $3.25^{\mathrm{c}}$ & $5.53^{\mathrm{d}}$ & $4.39^{\mathrm{d}}$ \\
\hline Blackgram + Maize & $4.92^{\mathrm{a}}$ & $4.42^{\mathrm{a}}$ & $4.67^{\mathrm{a}}$ & 149.73 & $4.56^{\mathrm{a}}$ & $7.51^{\mathrm{a}}$ & $6.03^{\mathrm{a}}$ \\
\hline Blackgram + Marigold & $4.46^{\mathrm{b}}$ & $3.80^{\mathrm{b}}$ & $4.13^{\mathrm{b}}$ & 120.86 & $3.47^{\mathrm{c}}$ & $6.63^{\mathrm{bc}}$ & $5.05^{\mathrm{c}}$ \\
\hline Blackgram + Okra & $3.16^{\mathrm{d}}$ & $2.45^{\mathrm{e}}$ & $2.80^{\mathrm{e}}$ & 49.73 & $2.60^{\mathrm{d}}$ & $4.94^{\mathrm{e}}$ & $3.77^{\mathrm{e}}$ \\
\hline Blackgram alone & $2.08^{\mathrm{e}}$ & $1.67^{\mathrm{f}}$ & $1.87^{\mathrm{f}}$ & - & - & - & - \\
\hline SED & 0.094 & 0.176 & 0.120 & & 0.172 & 0.273 & 0.108 \\
\hline CD $(0.05 \%)$ & 0.192 & 0.373 & 0.241 & & 0.362 & 0.575 & 0.210 \\
\hline
\end{tabular}

Mean of 3 replications

Figures were transformed by square root transformation and the original values are given In a columns means followed by same letter ( $\mathrm{s}$ ) are not significantly different $(\mathrm{P}=0.05)$ by DMRT 
Table.2 Effect of blackgram - non pulse intercropping systems on population of A. gossypii

\begin{tabular}{|l|c|c|c|c|c|c|c|}
\hline & \multicolumn{6}{|c|}{ Mean population of Aphis gossypii (No./ terminal shoot) on } \\
\cline { 2 - 8 } & \multicolumn{4}{|c|}{ Blackgram } & \multicolumn{3}{c|}{ Intercrop } \\
\cline { 2 - 8 } & Season 1 & $\begin{array}{c}\text { Season } \\
\text { II }\end{array}$ & $\begin{array}{c}\text { Pooled } \\
\text { Mean }\end{array}$ & $\begin{array}{c}\text { Percent } \\
\text { decrease }\end{array}$ & Season 1 & Season II & $\begin{array}{c}\text { Pooled } \\
\text { Mean }\end{array}$ \\
\hline Blackgram + Sunflower & $4.56^{\mathrm{a}}$ & $4.41^{\mathrm{a}}$ & $4.48^{\mathrm{a}}$ & 38.38 & $3.83^{\mathrm{a}}$ & $4.87^{\mathrm{a}}$ & $4.35^{\mathrm{a}}$ \\
\hline Blackgram + Sesame & $5.16^{\mathrm{b}}$ & $5.57^{\mathrm{cd}}$ & $5.36^{\mathrm{b}}$ & 26.27 & $4.40^{\mathrm{ab}}$ & $5.44^{\mathrm{b}}$ & $4.92^{\mathrm{b}}$ \\
\hline Blackgram + Sorghum & $5.89^{\mathrm{c}}$ & $5.25^{\mathrm{c}}$ & $5.57^{\mathrm{bc}}$ & 23.38 & $5.35^{\mathrm{c}}$ & $6.15^{\mathrm{d}}$ & $5.75^{\mathrm{c}}$ \\
\hline Blackgram + Maize & $6.11^{\mathrm{d}}$ & $4.85^{\mathrm{bc}}$ & $5.48^{\mathrm{b}}$ & 24.62 & $5.69^{\mathrm{c}}$ & $6.35^{\mathrm{d}}$ & $6.02^{\mathrm{cd}}$ \\
\hline Blackgram +Marigold & $4.88^{\mathrm{a}}$ & $4.57^{\mathrm{b}}$ & $4.72^{\mathrm{a}}$ & 35.08 & $4.08^{\mathrm{a}}$ & $5.15^{\mathrm{b}}$ & $4.61^{\mathrm{a}}$ \\
\hline Blackgram + Okra & $5.64^{\mathrm{c}}$ & $5.86^{\mathrm{d}}$ & $5.75^{\mathrm{c}}$ & 20.91 & $4.74^{\mathrm{b}}$ & $5.53^{\mathrm{bc}}$ & $5.13^{\mathrm{b}}$ \\
\hline Blackgram alone & $7.84^{\mathrm{e}}$ & $6.71^{\mathrm{e}}$ & $7.27^{\mathrm{d}}$ & - & - & - & - \\
\hline SED & 0.227 & 0.173 & 0.158 & & 0.228 & 0.208 & 0.182 \\
\hline CD $(0.05 \%)$ & 0.473 & 0.361 & 0.312 & & 0.465 & 0.422 & 0.365 \\
\hline
\end{tabular}

Table.3 Effect of blackgram - non pulse intercropping systems on pest defender ratio, occurrence ratio, preference ratio and cost benefit ratio

\begin{tabular}{|l|c|c|c|c|c|}
\hline \multirow{2}{*}{ Treatments } & \multicolumn{2}{|c|}{ Pest Defender ratio on } & $\begin{array}{c}\text { Occurrence } \\
\text { ratio of } \\
\text { predators }\end{array}$ & $\begin{array}{c}\text { Preference } \\
\text { ratio of pest }\end{array}$ & $\begin{array}{c}\text { Cost benefit } \\
\text { ratio }\end{array}$ \\
\hline Blackgram + Sunflower & $1: 1.77$ & $1: 2.80$ & 1.36 & 0.79 & $1: 4.96$ \\
\hline Blackgram + Sesame & $1: 1.18$ & $1: 1.64$ & 1.26 & 0.88 & $1: 3.79$ \\
\hline Blackgram + Sorghum & $1: 1.50$ & $1: 1.55$ & 1.23 & 1.03 & $1: 4.30$ \\
\hline Blackgram + Maize & $1: 2.31$ & $1: 2.18$ & 1.43 & 1.10 & $1: 4.84$ \\
\hline Blackgram +Marigold & $1: 1.66$ & $1: 2.42$ & 1.30 & 0.95 & $1: 4.52$ \\
\hline Blackgram + Okra & $1: 0.89$ & $1: 1.33$ & 1.19 & 1.17 & $1: 3.49$ \\
\hline Blackgram alone & $1: 0.37$ & - & - & - & $1: 2.11$ \\
\hline
\end{tabular}

Table.4 Behavioral response of coccinellids towards leaf and flower samples of blackgram and non-pulse intercrops by olfactometer

\begin{tabular}{|l|c|c|c|c|c|c|c|c|c|c|c|c|}
\hline \multirow{2}{*}{ Treatments } & \multicolumn{4}{|c|}{ No. attracted towards leaves at MAR } & \multicolumn{5}{c|}{ No. attracted towards flowers at MAR } \\
\cline { 2 - 14 } & $\mathbf{5}$ & $\mathbf{1 0}$ & $\mathbf{1 5}$ & $\mathbf{2 0}$ & Mean & $\begin{array}{c}\text { Percent } \\
\text { attraction }\end{array}$ & $\mathbf{5}$ & $\mathbf{1 0}$ & $\mathbf{1 5}$ & $\mathbf{2 0}$ & $\begin{array}{c}\text { Mean } \\
\text { Percent } \\
\text { attraction }\end{array}$ \\
\hline Sunflower & $2.00^{\mathrm{a}}$ & $2.66^{\mathrm{a}}$ & $2.66^{\mathrm{a}}$ & $3.00^{\mathrm{b}}$ & $2.58^{\mathrm{a}}$ & 12.90 & $1.66^{\mathrm{a}}$ & $3.00^{\mathrm{a}}$ & $3.00^{\mathrm{a}}$ & $3.33^{\mathrm{b}}$ & $2.75^{\mathrm{a}}$ & 13.75 \\
\hline Sesame & $1.33^{\mathrm{b}}$ & $1.66^{\mathrm{b}}$ & $2.00^{\mathrm{c}}$ & $2.33^{\mathrm{d}}$ & $1.83^{\mathrm{c}}$ & 9.15 & $1.66^{\mathrm{a}}$ & $1.66^{\mathrm{c}}$ & $2.66^{\mathrm{b}}$ & $3.00^{\mathrm{c}}$ & $2.25^{\mathrm{c}}$ & 11.25 \\
\hline Sorghum & $0.66^{\mathrm{c}}$ & $1.66^{\mathrm{b}}$ & $2.33^{\mathrm{b}}$ & $2.66^{\mathrm{c}}$ & $1.83^{\mathrm{c}}$ & 9.15 & $1.00^{\mathrm{c}}$ & $1.33^{\mathrm{d}}$ & $2.66^{\mathrm{b}}$ & $2.66^{\mathrm{d}}$ & $1.91^{\mathrm{d}}$ & 9.55 \\
\hline Maize & $1.33^{\mathrm{b}}$ & $1.33^{\mathrm{c}}$ & $2.66^{\mathrm{a}}$ & $3.33^{\mathrm{a}}$ & $2.16^{\mathrm{b}}$ & 10.80 & $1.66^{\mathrm{a}}$ & $2.33^{\mathrm{b}}$ & $2.66^{\mathrm{b}}$ & $3.66^{\mathrm{a}}$ & $2.58^{\mathrm{b}}$ & 12.90 \\
\hline Marigold & $0.66^{\mathrm{c}}$ & $1.66^{\mathrm{b}}$ & $2.66^{\mathrm{a}}$ & $3.00^{\mathrm{b}}$ & $2.00^{\mathrm{bc}}$ & 10.00 & $1.33^{\mathrm{b}}$ & $1.66^{\mathrm{c}}$ & $2.33^{\mathrm{c}}$ & $2.66^{\mathrm{d}}$ & $2.00^{\mathrm{d}}$ & 10.00 \\
\hline Okra & $0.33^{\mathrm{d}}$ & $0.66^{\mathrm{d}}$ & $1.66^{\mathrm{d}}$ & $2.00^{\mathrm{e}}$ & $1.16^{\mathrm{d}}$ & 5.80 & $0.66^{\mathrm{d}}$ & $1.33^{\mathrm{d}}$ & $2.00^{\mathrm{d}}$ & $2.33^{\mathrm{e}}$ & $1.58^{\mathrm{e}}$ & 7.90 \\
\hline Blackgram & $0.33^{\mathrm{d}}$ & $0.66^{\mathrm{d}}$ & $0.66^{\mathrm{e}}$ & $1.00 \mathrm{f}$ & $0.66^{\mathrm{e}}$ & 3.30 & 0.33 & 0.66 & $1.00^{\mathrm{e}}$ & $1.66^{\mathrm{f}}$ & 0.91 & 4.55 \\
\hline S. Ed & 0.054 & 0.036 & 0.094 & 0.107 & 0.074 & & 0.063 & 0.105 & 0.087 & 0.127 & 0.118 & \\
\hline CD $(0.05 \%)$ & 0.125 & 0.063 & 0.205 & 0.216 & 0.167 & & 0.124 & 0.216 & 0.174 & 0.251 & 0.234 & \\
\hline
\end{tabular}

Mean of 3 replications, MAR - Minutes after release

Figures were transformed by square root transformation and the original values are given

In a columns means followed by same letter $(\mathrm{s})$ are not significantly different $(\mathrm{P}=0.05)$ by DMRT 
Flowering crops can be used as attractant plants to encourage coccinellids such as $C$. sexmaculata, $C$. septempunctata and Brumoides suturalis in and around pulses (NIPHM, 2014). Accordingly, six other pulses were raised around blackgram. Among them, blackgram + sunflower, blackgram + marigold and blackgram + maize resulted in maximum population of coccinellids and minimum occurrence of aphids. Diversified ecosystems in the form of intercrops might have provided continuous availability of resources like proteins, vitamins and minerals to the coccinellids. The results substantiate the observations of that $C$. transversalis and $B$. suturalis were the dominant taxa in both rice and cowpea ecosystem Rekha et al., (2009). Similarly, Chandrasekar et al., (2016) also observed highest number of $C$. septempunctata on rice when border cropped with cowpea. According to them, other diversified cropping systems such as rice + sunflower, rice + okra, rice + sesame, rice + tomato and rice + brinjal also influenced higher population of coccinellids on rice. These findings are in corroboration with the resource abundance hypothesis of ecological engineering concept that plants, which offer more resources, have the potential to support more species and greater abundances of insect predators Hunter and Wilmer, (1989).

In the present study, increased availability of grubs and adults of coccinellids due to sunflower, maize and marigold intercrops might be reason for the less occurrence of aphids on blackgram. It was attributed that aphids infesting maize might have provided highly preferred prey to coccinellids for their survival and multiplication. Similar results were obtained in rice + cowpea border cropping system which registered maximum population coccinellids and rove beetle on rice and border crops and minimum population of plant hoppers and leafhoppers on rice (Chandrasekar et al., 2016). Okra + cowpea border cropping system registered a maximum population of dragonflies, damselflies, wasps, predatory pentatomid bugs and coccinellids on okra and border crops, and reduced the population of Bemisia tabaci and Helicoverpa armigera on okra. These border cropping systems also had the highest population of ichneumonid and braconid wasps and tachinid flies on okra and trap crops. These conditions resulted in higher occurrence ratio of natural enemies, higher pest defender ratio, higher yield and cost benefit ratio (Deepika, 2016). The findings are also in line with (Bharathi and Muthukrishnan, 2014) who found that cotton + okra, cotton + brinjal and cotton + tomato trap cropping systems, and cotton intercropped with cowpea, green gram and blackgram situations registered a lower population of $P$. solenopsis on cotton, trap crops and intercrops. Preference ratio was less for okra, brinjal, and tomato trap crops and high for sunflower; and less for cowpea, green gram and blackgram and high for ground nut intercrops. These trap and intercropping systems also registered the highest population of coccinellids, chrysopids and spiders on cotton and trap and intercrops as they had higher occurrence ratio; higher yield and cost benefit ratio.

Blackgram + cowpea, blackgram + French bean and blackgram + cluster bean border cropping system registered a maximum population of coccinellids on blackgram and border crops, and reduced the population of Aphis gossypii and blackgram.

These conditions resulted in higher occurrence ratio of natural enemies, higher pest defender ratio, higher yield and cost benefit ratio Lokesh et al., (2017).

\section{Response of coccinellids towards leaf and} flower samples by olfactometer

Population of coccinellids attracted towards leaf and flower samples of non-pulse crops at 
5, 10, 15 and 20 minutes after release (MAR) in olfactometer are given in (Table 4). There were significant differences in the attraction of coccinellids in olfactometer arms due to leaf and flower samples of intercrops.

The order of preference of leaves for the coccinellids were sunflower $(2.58$ beetles and $12.90 \%$ attraction), maize ( 2.16 beetles and $10.80 \%)$, marigold (2.0 beetles and $10.0 \%$ attraction), sesame (1.83 beetles and $9.15 \%$ attraction), sorghum (1.83 beetles and $9.15 \%$ attraction), okra (1.16 beetles and $5.80 \%$ attraction) and blackgram ( 0.66 beetles and $3.30 \%$ attraction).

The order of preference of flowers for the coccinellids was sunflower $(2.75$ beetles and $13.75 \%$ attraction), maize ( 2.58 beetles and $12.90 \%$ attraction), sesame (2.25 beetles and $11.25 \%$ attraction), marigold (2.00 beetles and $10.00 \%$ attraction), sorghum (1.91 beetles and $9.55 \%$ attraction), okra (1.58 beetles and $7.90 \%$ attraction) and blackgram ( 0.91 beetles and $4.55 \%$ attraction).

Attraction of coccinellids towards sunflower plants may be due to extra floral nectars present in stipules and inflorescence stalk (Pemberton and Vandenberg, 1993) and flower shape and flower colour Vattala et al., (2006) and (Nicolson and Thornburg, 2007).

Ecological engineering of intercropping of blackgram with maize, sunflower and marigold could be a better choice for conserving the coccinellids species, which would in turn facilitate for the natural suppression of blackgram aphids.

After large scale field demonstration, and validation of data, the component can be well fitted into integrated pest management systems in blackgram ecosystem as environmentally safe and cost effective strategy in small farmer's holdings.

\section{Acknowledgement}

Authors are also thankful to Mr. K. Samynathan (progressive pulse farmer), Viraliur, Thodamuthur Union, Coimbatore District, Tamil Nadu for providing facilities for the conduct of experiments and Tamil Nadu Agricultural University, Coimbatore for granting permission to publish the results.

\section{References}

Akila, S., and Sundara Babu, P.C. 1994. Release of different doses of Trichogramma and its effect on internode borer, yield and quality of sugarcane. Sugarcane London. 2: 22-23

Anonymous. 2016. Tamil Nadu Agricultural University, Coimbatore.

Anonymous. Directorate of Economics and Statistics. Department of Agriculture and Cooperation, 2012

Bharathi, K., and Muthukrishnan N. 2014. Management of cotton mealybugs Phenococcus solenopsis (Tinsley) through intercropping system. In: Extended Summary book on National Symposium on Emerging Trends in EcoFriendly Insect Pest Management held at Tamil Nadu Agricultural University, Coimbatore, January 22-24, A.E. Publications, 357-359.

Chandrasekar, K., N. Muthukrishnan, R.P. Soundararajan, S. Robin, and N.K. Prabhakaran. 2016. Ecological Engineering Cropping Method for Enhancing Predator Coccinella septempunctata and Suppression of Planthopper, Nilaparvata lugens (Stal) in Rice. Advances in Life Sciences, 5(16).

Cullen, R., K.D. Warner, M. Jonsson and S.D. Wratten.2008. Economics and adoption of conservation biological control. Biological Control. 45: 272-280.

Deepika, A., 2016. Developing ecological engineering methods and enhancing endomophages and increasing pest suppression on okra. M.Sc. Thesis, Tamil 
Nadu Agric. Univ., Coimbatore, Tamil Nadu.

Gomez, K.A., and Gomez A.A. 1984. Statistical procedures for Agricultural Research. John Wiley and Sons, New Delhi. 680.

Gurr, G.M., S.D. Wratten and M.A. Altieri.2004. Ecological engineering: advances in habitat manipulation for arthropods. Collingwood (Australia): CSIRO Publishing. 232.

Hunter, M.D., and Wilmer P.G.1989. The potential for interspecific competition between two aborderance defoliators on oak: leaf damage and habitat quality. Ecological Entomology. 14: 267-277

Lokesh, S., N. Muthukrishnan, N. Ganapathy, J.R. Kannan Bapu and E. Somasundaram, 2017. Ecological engineering cropping methods enhance Coccinellids and suppress aphids Aphis gossypii (Glover) in blackgram, Journal of Entomology and Zoology Studies, 5(3): 1288-1294

Muthukrishnan, N., and Dhanasekaran, V. 2014. Management of cotton pink bollworm Pectinophora gossypiella (Saunders) through trap cropping system. In: Extended Summary book on National Symposium on Emerging Trends in EcoFriendly Insect Pest Management held at Tamil Nadu Agricultural University, Coimbatore, January 22-24, A.E. Publications. 326-32.

Muthukrishnan, N., B. Ananthraj, J. Jayaraj. 2015. Developing polyculture based ecological engineering methods in cotton for enhancing predators for the management of whiteflies. In Proc., of the International Conference on Innovative Insect Management Approaches for
Sustainable Agro-ecosystem. 138-141, Tamil Nadu Agricultural University, AC\&RI, Madurai.

National Institute of Plant Health Management.2014. The AESA based IPM. Brinjal 23

Nicolson, S.W., and Thornburg, R.W. 2007. Nectar chemistry. Nectaries and Nectar (eds. Nicolson SW, Nepi M. Pacini E.). 215-264, Springer, Netherlands.

Pemberton, R.W., and Vandenberg, N.J.1993. Extra floral nectar feeding by ladybird beetles (Coleoptera: Coccinellidae). Proceedings of the Entomological Society of Washington. 95: 139- 151.

Poorani, J., 2002. An annotated checklist of the coccinellidae (Coleoptera) (excluding Epilachinae) of the Indian Sub region Journal Oriental Insects. 36: 307-383.

Rekha, B.S., Ramkumar J, Kandibane M, Raguraman S, Swamiappan M, 2009. Diversity of coccinellids in cereals, pulses, vegetables and weeded and partially weeded rice-cowpea ecosystems in Madurai District of Tamil Nadu. Madras Agricultural Journal. 96: 251-264.

Vattala, H.D., S.D, Wratten, C.B, Phillips and F.L.Wackers. 2006. The influence of flower morphology and nectar quality on the longevity of a parasitoid biological control agent. Biological Control. 39: $179-185$.

Wanner, H., H. Gunther, D. Hein and S. 2006. Dorn Tracing spatial distribution of parasitism in fields with flowering plant strips using stable isotope marking. Biological Control. 2: 39.

www.agropedia.iitk.ac.in- 2016

\section{How to cite this article:}

Lokesh, S., N. Muthukrishnan, N. Ganapathy, J.R. Kannan Bapu and Somasundaram, E. 2017. Ecological Engineering of Intercropping in Blackgram Promotes Services of Coccinellids and Suppress Aphis gossypii (Glover). Int.J.Curr.Microbiol.App.Sci. 6(11): 1963-1972. doi: https://doi.org/10.20546/ijcmas.2017.611.233 